\title{
Behavior of subcutaneous tissue of rats in response to infected dentine associated with different endodontic irrigants
}

\section{Comportamento do tecido subcutâneo de ratos frente à dentina infectada e associada a diferentes irrigantes endodônticos}

\begin{abstract}
Purpose: To compare rat subcutaneous connective tissue reaction to dentine contaminated with Enterococcus faecalis associated with $0.9 \%$ sterile saline, $5.25 \%$ sodium hypochlorite ( $\mathrm{NaOCl}$ ) and $2 \%$ chlorhexidine gel $(\mathrm{CHX})$.

Methods: Dentine was crushed into powder and inoculated with E. faecalis. Tested substances were mixed with contaminated dentine and placed in polyethylene tubes. Ten male Wistar rats had their backs divided into four quadrants that received an implant containing one of the tested substances. An empty tube was used as a control. Five rats were randomly distributed for evaluation at time intervals of 24 hours and 72 hours. Tissue samples were histologically processed. Tissue reactions to experimental groups were evaluated under optical microscopes. Results: Groups of $5.25 \% \mathrm{NaOCl}$ induced greater inflammatory response after 24 hours and 72 hours. Compared to groups of $2 \% \mathrm{CHX}$, the groups of $0.9 \%$ sterile saline showed milder inflammatory reactions after 24 hours and more severe after 72 hours.

Conclusion: The results indicate that $5.25 \% \mathrm{NaOCl}$ group showed a higher inflammatory reaction to rat subcutaneous connective tissue and the $2 \%$ chlorhexidine group showed the least reaction.
\end{abstract}

Key words: Chlorhexidine; root canal irrigants; sodium hypochlorite; subcutaneous tissue

\section{Resumo}

Objetivo: Comparar a resposta do tecido subcutâneo de ratos frente a dentina contaminada com Enterococcus faecalis associado ao soro fisiológico $0.9 \%$, hipoclorito de sódio $5.25 \%$ $(\mathrm{NaOCl})$ ou clorexidina gel $2 \%(\mathrm{CHX})$.

Metodologia: Foi realizada a contaminação de dentina em pó com E. faecalis. As substâncias testadas foram misturadas com a dentina contaminada e inseridas em tubos de polietileno. Dez ratos Wistar tiveram os dorsos divididos em quatro quadrantes e cada quadrante recebeu um tubo com cada uma das misturas testadas. Um tubo vazio foi utilizado como controle. Os ratos foram distribuídos em dois grupos para avaliação no período de 24 e 72 horas. Os tecidos foram processados histologicamente e as reações teciduais foram avaliadas sobre microscopia de luz.

Resultados: Os grupos de $\mathrm{NaOCl}$ 5.25\% promoveram maiores reações inflamatória após 24 e 72 horas. Quando comparado com os grupos de CHX 2\%, os grupos de soro fisiológico $0.9 \%$ mostraram inflamação moderada após 24 horas e severa após 72 horas.

Conclusão: Os resultados indicaram que o grupo de $\mathrm{NaOCl} 5.25 \%$ apresentou maior reação inflamatória aos tecidos subcutâneos de rato e que o grupo de CHX $2 \%$ apresentou menor reação inflamatória.

Palavras-chave: Clorexidina; irrigantes endodônticos; hipoclorito de sódio; tecido conjuntivo

\author{
Tauby S. Coutinho-Filho a \\ Cláudio M. A. Ferreira ${ }^{b}$ \\ Emmanuel J. N. L. da Silva b \\ Francisco J. Souza-Filhoc
}

\begin{abstract}
- Department of Restorative Dentistry, Endodontic Division, State University of Rio de Janeiro (UERJ), Rio de Janeiro, RJ, Brazil

bSpecialty Training Course in Endodontics, State University of Rio de Janeiro (UERJ), Rio de Janeiro, RJ, Brazil

c Department of Restorative Dentistry - Endodontic Division, Piracicaba Dental School, State University of Campinas (UNICAMP), Piracicaba, SP, Brazil
\end{abstract}

\author{
Correspondence: \\ Emmanuel João Nogueira Leal da Silva \\ State University of Rio de Janeiro \\ Department of Restorative Dentistry \\ Endodontic Division \\ BI. 28 de setembro, 157 \\ Rio de Janeiro, RJ - Brazil \\ 20550-900 \\ E-mail: nogueiraemmanuel@hotmail.com
}

Received: January 10, 2012

Accepted: August 13, 2012

Conflict of Interests: The authors state that there are no financial and personal conflicts of interest that could have inappropriately influenced their work.

Copyright: (C) 2012 Coutinho Filho et al.; licensee EDIPUCRS. This is an Open Access article distributed under the terms of the Creative Commons AttributionNoncommercial-No Derivative Works 3.0 Unported License. 


\section{Introduction}

One of the goals of endodontic therapy is the removal of all vital or necrotic tissue, microorganisms, and microbial by-products from root canal system $(1,2)$. The mechanical action of endodontic instruments may remove most bacteria found in the canal space; however, in several situations the complete debridement of the root canal system is complicated by the presence of a complex anatomy (1). This complex anatomy can provide ideal locations for organic residues and bacteria lodged deep inside isthmuses, accessory canals, deltas, and dentinal tubules that cannot be reached even after careful mechanical instrumentation (3). To aid in the removal of debris and the disinfection of these areas, the use of various intracanal irrigants has been advocated (4).

Sodium hypochlorite $(\mathrm{NaOCl})$ is the most used irrigant in endodontic therapy, and its antimicrobial property has been widely reported, acting also as a lubrificant for instrumentation and flushing loose debris from root canals $(5,6)$. Although $\mathrm{NaOCl}$ has these great qualities, it is known to be extremely irritating to the periapical tissues, especially at higher concentrations (3). Spilling of $\mathrm{NaOCl}$ beyond the foramen may cause inflammatory reaction in the periapical tissues and severe pain (7).

Among the alternatives, chlorhexidine gluconate has been recommended as an auxiliary chemical substance $(3,8)$; in addition to being relatively non-toxic when compared to $\mathrm{NaOCl}(9)$ it has excellent antimicrobial power and prolonged time of action within the canal, called substantivity (3). These properties may offer a clinical advantage of chlorhexidine over $\mathrm{NaOCl}$ in infected teeth postoperative against resistant microorganisms $(3,8)$.

During canal instrumentation and irrigation, dentine chips, pulp tissue fragments, necrotic tissue, microorganisms, and intracanal irrigants may be extruded from the apical foramen (10). Nevertheless, little data is available about tissue reaction to endodontic irrigants associated with dentine chips and microorganisms. Thus, the aim of the present study was to compare the reaction of rat subcutaneous connective tissue in response to the implant of dentine infected with Enterococcus faecalis associated with $0.9 \%$ sterile saline, $5.25 \%$ sodium hypochlorite and $2 \%$ chlorhexidine gluconate gel.

\section{Methodology}

Thirty teeth from the Teeth Bank of the Rio de Janeiro State University (UERJ) had the crown portion removed and the roots sanded to cementum removal. Dentine was broken into smaller particles, which were then ground through a Ball Mill (SPEX CertiPrep, Metuchen, NJ, USA). Particles were obtained with size between 0.2 and $20 \mu \mathrm{m}$. Bacterial strains of Enterococcus faecalis (ATCC 29212, Rockville, MD, USA) were cultured in a TSB medium (Difco, MI, USA) for 24 hours to obtain the microbial pellet. After this growth, the strains were centrifuged and washed three times with buffered saline solution (PBS, Phosphate buffered saline) and the $\mathrm{pH}$ was adjusted to 7.2. The strains were then diluted in saline solution to obtain 0.5 turbidity on the McFarland scale, corresponding to $1.5 \times 10^{8}$ colony-forming units per milliliter.

The samples were divided into four groups according to the material to be tested:

- Group 1: empty tube (control group);

- Group 2: 0.9\% sterile saline;

- Group 3: 5.25\% sodium hypochlorite (B'Herzog - Rio de Janeiro, RJ, Brazil);

- Group 4: 2\% chlorhexidine gluconate gel (Endogel ${ }^{\circledR}$ Essencial Pharma - Itapetininga, SP, Brazil).

For each group, $150 \mu \mathrm{L}$ aliquots of bacterial suspension were mixed with $2 \mathrm{~g}$ of dentin powder until obtaining a homogenous pellet. Then, the contaminated dentin was mixed with $0.5 \mathrm{~mL}$ of the corresponding substance to the experimental group and placed inside polyethylene tubes.

Ten Wistar rats weighing 250-270g were used for experiments. The animals were housed in a temperaturecontrolled environment with water and food ad libitum. All experiments were conducted in accordance with the National guidelines on the welfare of experimental animals and after approval by the Ethics in Research Committee of the Dental School of Rio de Janeiro State University. Under general anesthesia with xylazine $(10 \mathrm{mg} / \mathrm{kg}$ body weight $)$ and $5 \%$ ketamine hydrochloride $(25 \mathrm{mg} / \mathrm{kg}$ body weight $)$, the dorsal of each animal was divided into four quadrants and a tube containing a different sample was inoculated in each quadrant. After the implantation of the cylinders, the incisions were closed by simple suture.

Evaluations were made 24 and 72 hours after the inoculation. In each examination period, five animals were euthanized with an overdose of anesthesia. The surgical parts containing tubes wrapped in conjunctive tissue were excised, stored in $10 \%$ formalin solution for 48 hours, washed in running water and thereafter embedded in paraffin blocks using standard procedures. Six-micrometer-thick sections were obtained from the paraffin-embedded specimens and stained with hematoxylin and eosin for histomorphological analysis under optical microscopy with a Zeiss - Axioplan 2 optical microscope (Carl Zeiss AG, Germany).

The microscopic analysis of the inflammatory process after the tube implantation consisted of a description or notification of the inflammatory infiltrate presence or absence. The type of infiltrate, acute or chronic, their intensity and extent were also evaluated. Exudate characteristics could be assessed by edema, abscess, or micro abscess presence. The presence or absence of tissue necrosis was also described.

\section{Results}

A qualitative analysis of histological results was performed, to determine if there was an inflammatory infiltrate in the periods studied, and if so, what type of inflammatory infiltrate was observed, to determine the biocompatibility of the materials studied. 

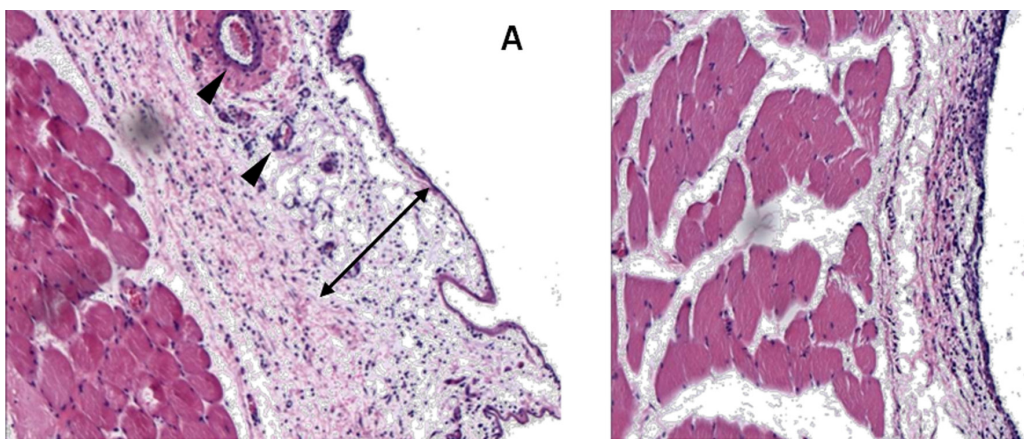

B

Fig. 1. Reaction of rat subcutaneous connective tissue to the empty tube (control group). (A) After 24 hours the subcutaneous tissue showed mild inflammatory infiltrate, moderate edema areas (double-headed arrow) and presence of blood vessels (arrowhead) in small number. (B) After 72 hours is possible to observe an edema reduction and chronic inflammatory infiltrate (H\&E, original magnification X100).
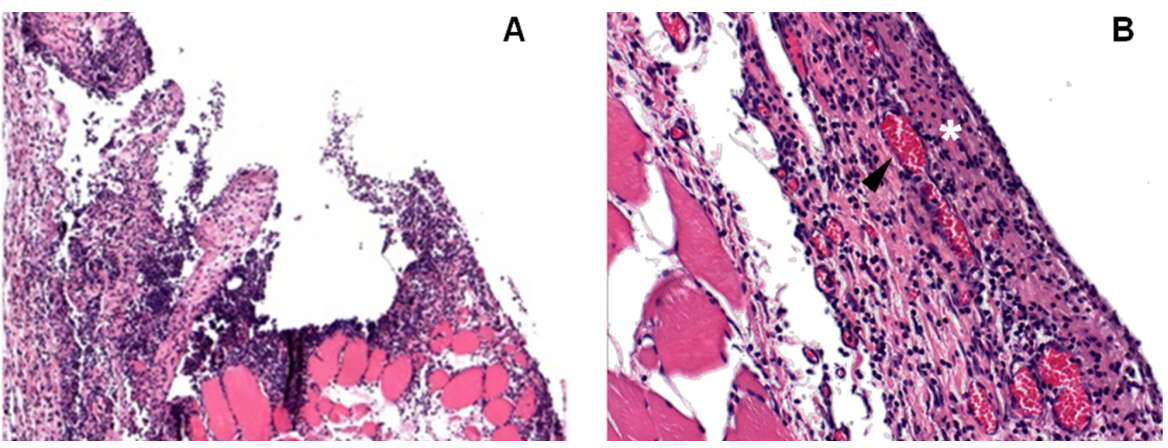

Fig. 2. Reaction of rat subcutaneous connective tissue to $0.9 \%$ sterile saline associated with infected dentine. (A) After 24 hours severe mononuclear and polymorph nuclear inflammatory infiltrate rich in neutrophils and intense edema areas (H\&E, original magnification X100). (B) After 72 hours the assessed area presented an acute inflammation rich in neutrophils, mononuclear infiltrate severe edema, hyperemic blood vessels (arrowhead), small areas of tissue necrosis and micro abscesses (white star) (H\&E, original magnification X200).
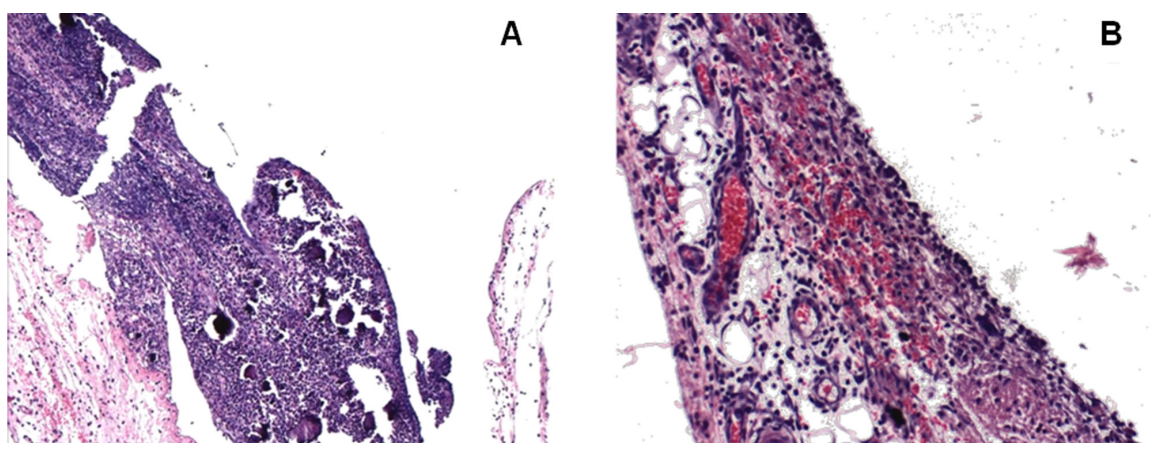

Fig. 3. Reaction of rat subcutaneous connective tissue to $5.25 \% \mathrm{NaOCl}$ associated with infected dentine. (A) After 24 hours subcutaneous tissue presented large areas of intense inflammatory infiltrate rich in neutrophils, severe edema, some areas of tissue destruction and many dilated and hyperemic blood vessels ( $H \& E$, original magnification $\mathrm{X} 100$ ). (B) After 72 hours the assessed area presented intense inflammatory infiltrate rich in neutrophils, large areas of edema, larger areas of tissue necrosis than in the 24 hours period, presence of abscesses and a large number of dilated and hyperemic blood vessels (H\&E, original magnification X200).
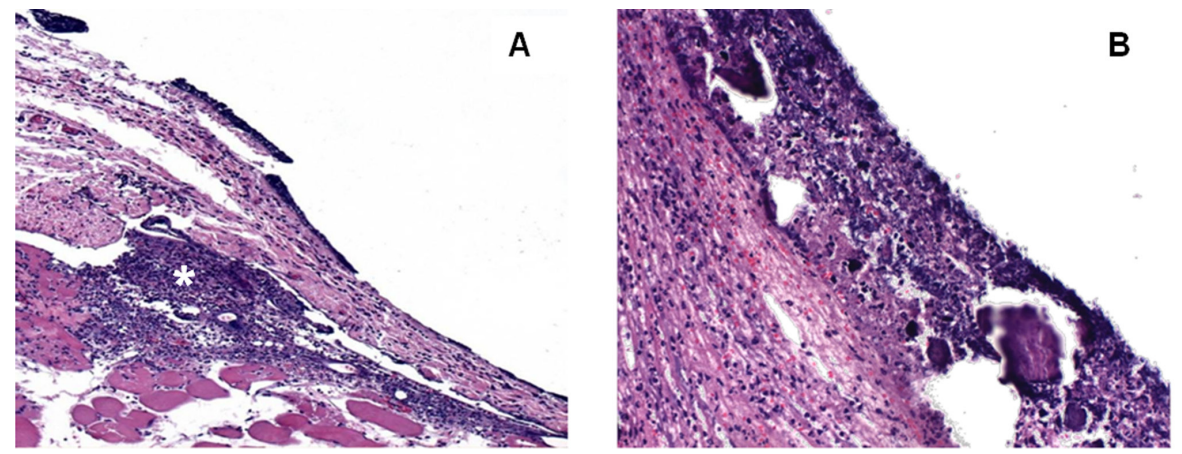

Fig. 4. Reaction of rat subcutaneous connective tissue to $2.0 \%$ Chlorhexidine gel associated with infected dentine. (A) After 24 hours it is possible to observe moderate to intense inflammatory infiltrate (white star), with presence of polymorphonuclear and mononuclear cells, severe edema, some areas of tissue necrosis and small number of hyperemic blood vessels (H\&E, original magnification X100). (B) After 72 hours the assessed area showed intense inflammatory infiltrate rich in neutrophils and mononuclear cells, intense edema, larger areas of necrosis, low number of hyperemic blood vessels and no abscess (H\&E, original magnification X200). 


\section{Empty tube (control)}

As shown in Fig. 1, the histological findings in this group were similar in 24 hours and 72 hours. In the 24-hour period, the subcutaneous tissue showed mild inflammatory infiltrate, moderate edema areas, and presence of blood vessels in small number. In the 72-hour period an edema reduction and chronic inflammatory infiltrate presence were observed.

\section{Saline solution}

In the 24-hour period, the histological section showed severe mononuclear and polymorph nuclear inflammatory infiltrate rich in neutrophils, and intense edema areas. In the 72-hour period, the assessed area presented an acute inflammation rich in neutrophils, mononuclear infiltrate, severe edema, hyperemic blood vessels, small areas of tissue necrosis, and micro abscesses (Fig. 2).

\section{Sodium hypochlorite}

In the 24-hour period, the subcutaneous tissue presented large areas of intense inflammatory infiltrate rich in neutrophils, severe edema, some areas of tissue destruction, and many dilated and hyperemic blood vessels. In the 72-hour period, the assessed area presented intense inflammatory infiltrate rich in neutrophils, large areas of edema, larger areas of tissue necrosis than in the $24 \mathrm{~h}$ period, a large number of dilated and hyperemic blood vessels, and presence of abscess (Fig. 3).

\section{Chlorhexidine}

In the 24-hour period, moderate to intense inflammatory infiltrate was observed, with the presence of polymorphonuclear and mononuclear cells, severe edema, some areas of tissue necrosis, and a small number of hyperemic blood vessels. In the 72-hour period, the area assessed showed intense inflammatory infiltrate rich in neutrophils and mononuclear cells, intense edema, larger areas of necrosis, low number of hyperemic blood vessels, and no abscess (Fig. 4).

\section{Discussion}

During endodontic treatment, debris, auxiliary chemical substances, and bacteria are often pushed out of the apex, coming into direct contact with the periapical vital tissues (9). Infection is considered the most significant factor in the flareup pathogenesis $(11,12)$. The organic tissue associated with microorganisms that spill into the apical region during the canal preparation may cause acute inflammation reaction and severe pain. Enterococcus faecalis was the microorganism selected for this study for several reasons: it is the key species in several persistent endodontic infections; it is more resistant to some auxiliary chemical substances than other microorganisms; it is able to be active in these substances; and it is easy to grow and to identify (13-15).

Good tolerance of subcutaneous connective tissue to polyethylene tubes was shown in the present study. Little inflammatory response was observed in the control group. This inflammation could be caused by the aggression during tubes surgical implantation $(9,16)$. In the saline solution group intense inflammatory response was observed within the first 24 hours. This response was more intense after 72 hours. The results suggest that despite the low inflammatory reaction of the saline solution, the association with pathogenic microorganisms can lead to intense inflammatory response, as this solution does not have antimicrobial action (17).

The substances $5.25 \% \mathrm{NaOCl}$ and $2 \%$ chlorhexidine gel presented similar results at 24 hours. However, when compared to the 72-hour period, a more acute response was characterized in the hypochlorite group, with features not found in the chlorhexidine group, such as abscess formation, larger areas of necrosis, and more severe vascular changes. These results suggest the possibility of better antibacterial activity against $E$. faecalis of chlorhexidine compared to $\mathrm{NaOCl}$. Previous studies reported that $2 \%$ chlorhexidine has a more effective antimicrobial action after several days of the chemomechanical preparation $(10,18,19)$. This residual antimicrobial effect of chlorhexidine, called substantivity may be related to less tissue reaction caused after a 72hour period. Another factor that may be attributed to this difference in inflammatory response between the two groups is the inability of chlorhexidine to dissolve vital and necrotic tissue $(11,18,20)$, which makes it less aggressive than $\mathrm{NaOCl}$. Tissue dissolution may cause severe effects, such as hemolysis, ulceration, inhibition of neutrophil migration, damage to endothelial, damage to fibroblast cells, facial nerve weakness, and necrosis if the solution is extruded during endodontic treatment (21-24).

When compared to the saline solution group, the chlorhexidine group results in the 72-hour period had differences similar to those found in the hypochlorite group. Again, the antimicrobial power and the chlorhexidine substantivity may be related to these results. However, in the 24-hour period, the chlorhexidine group showed greater irritation to tissues, with necrosis areas and inflammatory infiltrate more intense than the saline solution group. These results may be attributed to an initial cytotoxicity of chlorhexidine (21). Gomes-Filho et al. (9) suggest that the chlorhexidine gel may promote a greater inflammatory response in the conjunctive tissue because the tissues would take longer to absorb it than when it's in its liquid form.

The authors report that if the antimicrobial effect were the only major requirement for an irrigating solution, chlorhexidine would be the choice irrigant (25). However, it is known that the ability of tissue dissolution of the hypochlorite is of great importance in root canal instrumentation. Some clinicians consider the lower chlorhexidine toxicity as an advantage insufficient to compensate for its inability to dissolve tissues (25). Therefore, the antimicrobial properties of an irrigant should not be the only concern in the choice of a chemical auxiliary substance. Concerns about biocompatibility and the tissue dissolution ability also exist, especially when there is a greater possibility of clinical spilling of these substances. 


\section{Conclusions}

In conclusion, the results of the present study indicate that $5.25 \% \mathrm{NaOCl}$ group showed the highest inflammatory reaction in rat subcutaneous connective tissue and the $2 \%$ chlorhexidine group showed the lowest.

1. Burleson A, Nusstein J, Reader A, et al. The in vivo evaluation of hand/rotary/ultrasound instrumentation in necrotic, human mandibular molars. J Endod 2007;33:782-7.

2. Ricucci D, Siqueira JF Jr. Fate of the tissue in lateral canals and apical ramifications in response to pathologic conditions and treatment procedures. J Endod 2010;36:1-15.

3. Ferraz CC, Gomes BP, Zaia AA, Teixeira FB, Souza FJ Filho. In vitro assessment of the antimicrobial action and the mechanical ability of chlorhexidine gel as an endodontic irrigant. J Endod $2001 ; 27: 452-5$.

4. Card SJ, Sigurdsson A, Orstavik D, Trope M. The effectiveness of increased apical enlargement in reducing intracanal bacteria. J Endod 2002;28:779-83.

5. Christensen CE, McNeal SF, Eleazer P. Effect of lowering the $\mathrm{pH}$ of sodium hypochlorite on dissolving tissue in vitro. J Endod 2008;34:449-52.

6. Arias-Moliz MT, Ferrer-Luque CM, Espigares-García M, Baca P. Enterococcus faecalis biofilms eradication by root canal irrigants. J Endod 2009;35:711-4.

7. Gernhardt CR, Eppendorf K, Kozlowski A, Brandt M. Toxicity of concentrated sodium hypochlorite used as an endodontic irrigant. Int Endod J 2004;37:272-80.

8. Dametto FR, Ferraz CC, Gomes BP, Zaia AA, Teixeira FB, de Souza-Filho FJ. In vitro assessment of the immediate and prolonged antimicrobial action of chlorhexidine gel as an endodontic irrigant against Enterococcus faecalis. O Surg $\bigcirc$ Med $\bigcirc$ Pathol $\bigcirc$ Radiol Endod 2005;99:768-72.

9. Gomes-Filho JE, Aurélio KG, Costa MM, Bernabé PF. Comparison of the biocompatibility of different root canal irrigants. J Appl Oral Sci 2008; 16:137-44.

10. Ferraz CC, Gomes NV, Gomes BP, Zaia AA, Teixeira FB, Souza-Filho FJ. Apical extrusion of debris and irrigants using two hand and three engine-driven instrumentation techniques. Int Endod J 2001;34:354-8.

11. Tsesis I, Faivishevsky V, Fuss Z, Zukerman O. Flare-ups after endodontic treatment: a metaanalysis of literature. J Endod 2008;10:1 177-81.

12. Alves Vde O. Endodontic flare-ups: a prospective study. Oral Surg Oral Med Oral Pathol Oral Radiol Endod 2010;110:68-72.

13. Haapasalo HK, Sirén EK, Waltimo TM, Ørstavik D, Haapasalo MP. Inactivation of local root canal medicaments by dentine: an in vitro study. Int Endod J 2000;33:126-31.

14. Rôças IN, Siqueira JF Jr. Characterization of the microbiota of root canal-treated teeth with post-treatment disease. J Clin Microbiol 2012. [Epub ahead of print]

15. Dagna A, Arciola CR, Florindi F, Scribante A, Saino E, Visai L, Poggio C. In vitro evaluation of antimicrobial efficacy of endodontic irrigants. Int J Artif Organs 2011 ;34:914-9.

16. Semenoff TA, Semenoff Segundo A, de Figueiredo JA. Biocompatibility of different intracanal medications in rat bucal submucosa tissue. J Appl Oral Sci 2008; 16:12-7.

17. Vianna ME, Gomes BP, Berber VB, Zaia AA, Ferraz CC, de Souza-Filho FJ. In vitro evaluation of the antimicrobial activity of chlorhexidine and sodium hypochlorite. $\bigcirc$ Surg $\bigcirc$ Med $\bigcirc$ Pathol O Rad Endod 2004;97:79-84.

18. Onçağ O, Hoşgör M, Hilmioğlu S, Zekioğlu O, Eronat C, Burhanoğlu D Comparison of antibacterial and toxic effects of various root canal irrigants. I Endod J 2003;36:423-32.

19. Withe RR, Hays GL, Janer LR. Residual antimicrobial activity after canal irrigation with chlorhexidine. J Endod 1997;23:229-31.

20. Okino LA, Siqueira EL, Santos M, Bombana AC, Figueiredo JA. Dissolution of pulp tissue by aqueous solution of chlorhexidine digluconate and chlorhexidine digluconate gel. Int Endod J 2004;37:38-41.

21. Spångberg LS, Engström B, Langeland K. Biologic effects of dental materials. Toxicity and antimicrobial effect of endodontic antiseptics in vitro. O Surg $\bigcirc$ Med Oral Pathol 1973;36:856-71.

22. Pelka M, Petschelt A. Permanent mimic musculature and nerve damage caused by sodium hypochlorite: a case report. Oral Surg Oral Med Oral Pathol Oral Radiol Endod 2008;106:80-3.

23. De Sermeño RF, da Silva LA, Herrera H, Herrera H, Silva RA, Leonardo MR. Tissue damage after sodium hypochlorite extrusion during root canal treatment. Oral Surg Oral Med Oral Pathol Oral Radiol Endod 2009; 108:46-9.

24. Kerbl FM, DeVilliers P, Litaker M, Eleazer PD. Physical effects of sodium hypochlorite on bone: an ex vivo study. J Endod 2012;38:357-9.

25. Zehnder M, Kosicki D, Luder H, Sener B, Waltimo T. Tissue-dissolving capacity and antibacterial effect of buffered and unbuffered hypochlorite solutions. $\bigcirc$ Surg $\bigcirc$ Med $\bigcirc$ Pathol O Rad Endod 2002;94:756-62. 